DOI: $10.12731 / 2227-930 X-2017-2-56-63$

\title{
CALCULATION PECULIARITIES OF RE-PROCESSED ROAD COVERING UNIT COST
}

\section{Izmaylova D.K., Seliverstov N.D.}

In the article there are considered questions of economic expediency of non-waste technology application for road covering repair and restoration. Determined the conditions of asphalt-concrete processing at plants. Carried out cost changing analysis of asphalt granulate considering the conditions of transportation and preproduction processing. Given an example of expense calculation of one conventional unit of asphalt-concrete mixture volume preparation with and without processing.

Keywords: processing; road coverage; repair; asphalt granulate; material transportation; cost price.

\section{Introduction}

Reduction cost of construction, repair and restoration of road surfaces is ensured at the stage of project planning, by optimizing the mechanization, parameters and operating modes of individual units. The dislocation of asphalt mixing equipment from the site of production determines the formation of mechanization complexes [4]. The restoring cost of the road coverage is made up of the cost of machine-hours and the cost of building materials with delivery to the place of production $[2,3$, $7,8]$. The unit cost of production is determined by the equation:

$$
C_{E \Pi}=\frac{C_{M Y}}{\Pi}+C_{M Д}, \mathrm{rub} . / \mathrm{m}^{3},
$$

$C_{M Y}$ - the prime cost of complex's operation machine-hour, rub./h; $\Pi$ - operating capacity of the complex, $\mathrm{m}^{3} / \mathrm{h}$; $C_{\text {мд }}$ - cost of building material with delivery, rub. $/ \mathrm{m}^{3}$.

To estimate expenditures of restoring road surface using a nonwaste technology there are several ways of implementing the repair process: 
1) without recycling old pavement materials;

2) during cyclic processing on a remote mixing equipment (stationary / mobile plant / asphalt mixing plant);

3) during continuous recycling by the recycler in the process of removing / laying the coating in conjunction with machines that are feeding binder and / or cement-water suspension.

In the first and second options, there are used dump trucks and front loaders to transport materials between cycles. In the last two options, the percentage of recycled material in the new mixture is preset.

The volumes of finished products and transportation conditions of asphalt-concrete mixture to the place of work affect its production. Stationary plants are usually constructed in regions with a high constant demand for building materials. In uncertain conditions of mixture production volumes there are used mobile asphalt plants with various mobility.

The cost of 1 ton of a new hot asphalt mix without processing the granulate is determined by the equation:

$$
C_{C M}^{\Gamma A C}=C_{I I}+C_{M I I}+C_{B B} \text {, rub. }
$$

$C_{\Pi}-$ cost of a sand component in a ton of mixture, rub;

$C_{M I}$ - cost of a mineral powder component in a ton of mixture, rub;

$C_{B B}$ - cost of a binder component in a ton of mixture, rub.

An example of calculating the material cost in an asphalt-concrete mixture without granulate is given in Table 1.

Table 1.

Calculation of the material cost in asphalt-concrete mixture without granulate

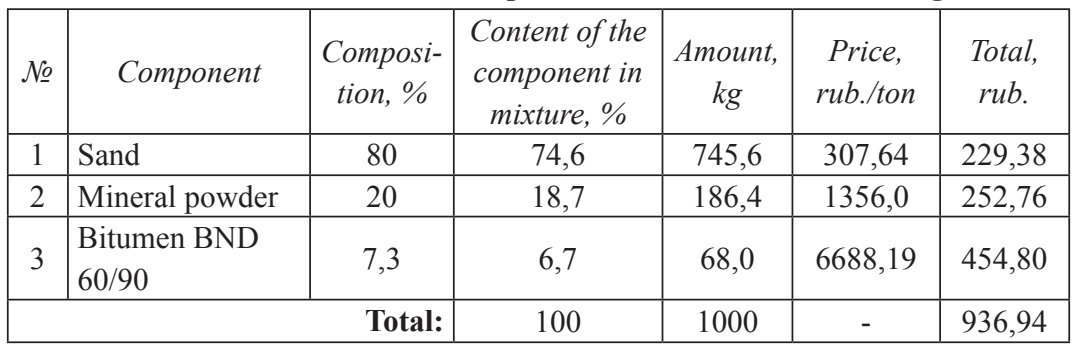


The main condition of economically efficient processing is the excess of a new hot asphalt mixture cost without granulate processing $C_{C M}^{\Gamma A C}$ the mixture cost on the basis of the processed granulate $C_{C M}^{P A I}$ considering granulate and mixtures transportation between the work place and asphalt-concrete plant:

$$
C_{C M}^{\Gamma A C} \geq C_{C M}^{P A \Pi} \text { or } \frac{C_{C M}^{\Gamma A C}}{C_{C M}^{P A \Pi}} \geq 1 .
$$

The preparation of a new mixture with the use of asphalt granulate provides for its fragmentation into smaller fractions, sieving into fractions and surface processing [6,9]. Calculating the cost of asphalt granulate crushing that goes to asphalt-concrete plant after milling is given in Table 2. Different RAP fractions, depending on the crushing degree can replace sand, mineral powder or both mineral components in the new mixture.

The mixture cost on the basis of RAP is determined by the equation:

$$
C_{C M}^{P A I I}=C_{P A I I}+C_{Z P O B}+C_{B B} \text {, rub }
$$

$C_{P A \Pi}$ - the asphalt granulate cost in a ton of the mixture with delivery to the plant, rub.;

$C_{Д Р О Б}-$ the cost of asphalt granulate crushing supplied to the plant after milling, rub.;

$C_{B B}-$ cost of binder component in a ton of mixture, rub.

Table 2.

Calculation of asphalt granulate crushing cost supplied to the plant after milling

\begin{tabular}{|c|c|c|}
\hline № & Expenditures & Total, rub. \\
\hline 1 & Salaries & 1837,85 \\
\hline 2 & Salary charges & 524,60 \\
\hline 3 & Electricity & 6751,36 \\
\hline 4 & Dump truck (15 t) & 6413,80 \\
\hline 5 & Front loader & 9597,72 \\
\hline 6 & Repairing costs & 1182,50 \\
\hline 7 & Total direct costs & 26297,83 \\
\hline 8 & Overhead (15\%) & 3944,67 \\
\hline 9 & Total 500 tons & 30242,50 \\
\hline 10 & Total 1 ton & 60,49 \\
\hline
\end{tabular}


The above crushing regimes provide a fraction that replaces the sand components in the new mixture. To obtain a finer fraction of the mineral powder component, additional crushing and costs are necessary. Consider the option of the maximum use of asphalt granules in a new mixture on the plant. In this case, while calculating the cost of crushing an asphalt granulate that arrives at the plant after milling, a dimensionless correction coefficient is used, which value is in the range $\mathrm{k}=1,5 \div 4$ and is selected depending on the production conditions [5].

Asphalt granulate is obtained by removing the coating layer. The cost can be considered zero, since the removal of the old layer is a technological operation of repair / reconstruction of the road and is performed regardless of the repeated use of the materials obtained in construction.

The cost of asphalt granulate (RAP) is formed during its delivery to the place of mixture preparation and is determined by the equation:

$$
C_{P A I I}^{\Sigma}=\sum_{i=1}^{n}\left(C_{P_{A I I}} \cdot Q_{P A I I}+\frac{C_{M 4} \cdot l \cdot Q_{P A I}}{Q_{T C}^{2} \cdot V_{T C}}\right)=\frac{C_{M 4} \cdot l \cdot Q_{P A I I}}{Q_{T C}^{2} \cdot V_{T C}} \mathrm{rub} . / \mathrm{m}^{3} .
$$

The asphalt granulate cost calculated based on weight:

$$
C_{\text {PAIД }}^{\Sigma}=\frac{C_{M Y} \cdot l \cdot Q_{P A I I}}{Q_{T C}^{2} \cdot V_{T C} \cdot \rho_{\text {PAII }}}, \text { rub. } / \mathrm{kg}
$$

$\rho_{P A I I}$ - the density of asphalt granulate, $\mathrm{kg} / \mathrm{m}^{3}$ (for black rubble granulate $\rho_{P A I I}=1600, \mathrm{~kg} / \mathrm{m}^{3}$ ); other notation were given earlier.

Considering special options of granulate delivery for one transport operation and delivery of granulate in a larger volume, at the first option (one transport delivery) we receive:

$$
\begin{aligned}
& Q_{\text {PAח }}=Q_{T C}, \\
& C_{\text {РАПД }}=\frac{C_{\text {МчД }} \cdot l}{Q_{T C} \cdot V_{T C} \cdot \rho_{\text {РАII }}}, \text { rub. } / \mathrm{kg} \text {, }
\end{aligned}
$$

Examination of the RAP cost changing for the given delivery conditions (Table 2) with a variable transportation distance $l=v a r$ depending on the distance between plant and place where the RAP was obtained (Figure 3): 


$$
\begin{gathered}
C_{\text {МчД }}=2000, \mathrm{rub} . / \mathrm{h} ; Q_{T C}=15, \mathrm{~m}^{3} ; V_{T C}=45, \mathrm{~km} / \mathrm{h} ; \rho_{\text {РАП }}=1600, \mathrm{~kg} / \mathrm{m}^{3} ; \\
C_{\text {РАПД }}=\frac{2000 \cdot l}{15 \cdot 45000 \cdot 1600}=1,85 \cdot 10^{-6} \cdot \mathrm{l}, \mathrm{rub} . / \mathrm{kg}, \\
C_{\text {РАПД }}^{=} 1,85 \cdot 10^{-3} \cdot l, \mathrm{rub} . / \mathrm{ton}
\end{gathered}
$$

Examination of the RAP cost changing when it is necessary to deliver the granulate in several transport operations. For given delivery conditions with variable transportation distance $l=$ var we get:

$C_{\text {мчд }}=2000$, rub./h;

$Q_{\text {РАП }}=1000, \mathrm{~m}^{3}$;

$Q_{T C}=15, \mathrm{~m}^{3}$;

$V_{T C}=45, \mathrm{~km} / \mathrm{h}$;

$\rho_{P A \Pi}=1600, \mathrm{~kg} / \mathrm{m}^{3}$;

The cost calculations of asphalt granulate based on weight:

$$
\begin{aligned}
& C_{\text {PАाД }}^{\Sigma}=\frac{2000 \cdot 1000 \cdot l}{15^{2} \cdot 45000 \cdot 1600}=1,234 \cdot 10^{-4} \cdot l, \mathrm{rub} . / \mathrm{kg} \text {. } \\
& \tilde{N}_{Ð \dot{A} \ddot{I} \ddot{A}}^{\sum}=0,1234 \cdot l \text {, rub./t. }
\end{aligned}
$$

A cost comparison of asphalt granulate on plant in particular delivery options in one transport operation and granulate delivery in a larger volume is shown in Fig. 1.

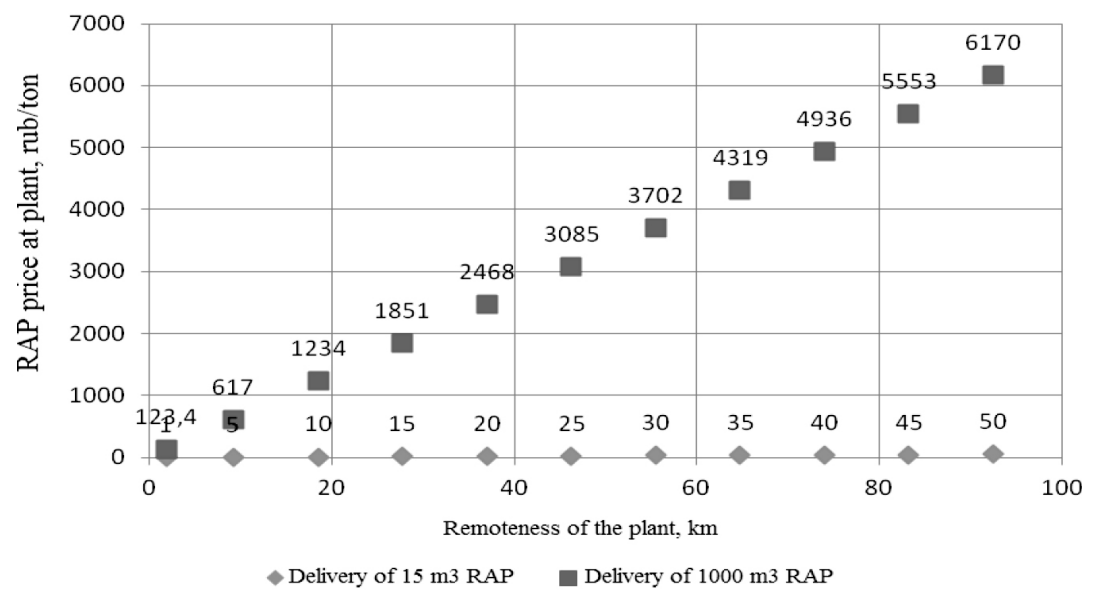

Fig. 1. Price change of asphalt granulate at plant for delivery of $15 \mathrm{~m}^{3}$ and for delivery of $1000 \mathrm{~m}^{3}$, depending on the remoteness of the plant from the place of receipt of the granulate and the specified conditions for the transportation mechanization. 
Consideration of a special option of using asphalt granulate after crushing (Table 3), where the cost of a ton of granulate is determined mainly by the fragmentation cost of the fraction.

Table 3.

Cost calculation of the materials

in an asphalt mix using asphalt granulate after crushing

\begin{tabular}{|c|c|c|c|c|c|c|}
\hline № & Component & $\begin{array}{c}\text { Composi- } \\
\text { tion, } \%\end{array}$ & $\begin{array}{c}\text { Content of } \\
\text { the compo- } \\
\text { nent in mix- } \\
\text { ture, } \%\end{array}$ & $\begin{array}{c}\text { Amount, } \\
\mathrm{kg}\end{array}$ & $\begin{array}{l}\text { Price, } \\
\text { rub./ton }\end{array}$ & $\begin{array}{l}\text { Total, } \\
\text { rub. }\end{array}$ \\
\hline 1 & $\begin{array}{l}\text { Asphalt granulate } \\
\text { (crushed) } \\
\text { Sand }\end{array}$ & 63 & \multirow{2}{*}{$93-95 \%$} & \multirow{2}{*}{940,0} & 399,47 & \multirow{2}{*}{375,5} \\
\hline 2 & $\begin{array}{l}\text { Asphalt granulate } \\
\text { (crushed) } \\
\text { Mineral powder }\end{array}$ & 17 & & & 399,47 & \\
\hline 3 & Bitumen BND 60/90 & 6,2 & 5,84 & 58,4 & 6688,19 & 390,59 \\
\hline & & Total: & 100 & 1000 & - & 766,1 \\
\hline
\end{tabular}

* - Limitation. Calculating the final RAP cost, mathematical models do not take into account the cost of RAP sieving into different fractions, as well as the addition of surfactants and plasticizers.

The decision to use the technology of re-use of asphalt granules while processing it on plant is made on the basis of inequality (2) after calculating the preparing costs of 1 ton of asphalt mixture without granulate and with granulate. Example is given in Table 4 [5].

Table 4.

Cost calculations for preparation of 1 ton of asphalt-concrete mixture (type D)

\begin{tabular}{|c|l|c|c|}
\hline \multirow{2}{*}{ № } & \multicolumn{2}{|c|}{ Expenditures } & \multicolumn{2}{c|}{ Composition } \\
\cline { 3 - 4 } & & With no granulate & With granulate \\
\hline 1 & Raw materials & 936,94 & 766,1 \\
\hline 2 & Fuel & 43,97 & 43,97 \\
\hline 3 & Electricity & 22,4 & 22,4 \\
\hline 4 & Basic salary & 40,07 & 40,07 \\
\hline 5 & Social insurance deductions & 11,22 & 11,22 \\
\hline 6 & Depreciation & 19,37 & 19,37 \\
\hline 7 & Rent & 36,79 & 36,79 \\
\hline 8 & Security & 3,16 & 3,16 \\
\hline 9 & Overheads & 129,48 & 129,48 \\
\hline 10 & Production cost & 1243,04 & 1072,39 \\
\hline
\end{tabular}


In the case of asphalt granules maximum use in the new mixture while preparing on plant, the amount of binder is comparable. Inequality (2) can be simplified to the form:

$$
\begin{gathered}
C_{I I}+C_{M I I} \geq C_{P A I I}+C_{\text {ДРОБ }} ; \\
\frac{C_{I I}+C_{M I I}}{C_{P A I I}+C_{\text {ДPOS }}} \geq 1 .(5)
\end{gathered}
$$

Based on inequalities (2) and (5), transport conditions and maximum transportation distance are determined, which ensures the economic processing efficiency.

\section{Conclusion}

To determine the production cost, calculations for each nomenclature are made separately. Based on the production cost calculation, settlement prices are set, which in turn are the basis for the organization of the system of mutual settlements of production units.

The granulate cost $C_{P A I}$ is determined mainly by the volume of RAP delivery, the distance of transportation and operating characteristics of the vehicle (transport time, body / hopper volume). The RAP cost can vary from zero to infinity. Under certain conditions, the use of RAP becomes irrational due to the cost excess of the mixture based on the RAP compared to the cost of the new hot asphalt mix.

\section{References}

1. Izmaylova D.K., Dreytsen M.A. Improving indicators of motor complex organization on the basis of modern concepts of functioning // Economics and society 2015. №2-2 (15), pp. 686-688.

2. Izmaylova D.K., Seliverstov N.D. Evaluation of the restoring costs of road surface based on non-waste technology work // Repair, restoration, modernization. 2017. № 3, pp. 38-44.

3. Izmaylova D.K., Seliverstov N.D. Economics of non-waste technologies in Russia // Repair, restoration, modernization. 2016. № 12, pp. 37-40.

4. Kustarev G.V., Seliverstov N.D. Ways of development of recycling pavements technologies in Russia // Building equipment. 2015. №12 (858), pp. 4-8. 
5. Lupanov A.P. Processing of asphalt concrete on plants. Moscow: Ekon-Inform, 2012. $210 \mathrm{p}$.

6. Seliverstov N.D. Selection of the asphalt-concrete mixtures composition for the road surface recycling // All materials. Encyclopedic reference book. 2015. № 7, pp. 40-45.

7. Izmaylova D.K., Seliverstov N.D. Economy of a Non-waste Road Repairing and Covering Technology in Different Countries // International Journal of Advanced Studies. 2016. Vol. 6. № 3, pp. 3-6. DOI: 10.12731/2227-930X-2016-3-1.

8. Izmaylova D.K., Seliverstov N.D. Economic Indicators of Road Surfaces Reconstructions in the World Using Non-waste Technology // International Journal of Advanced Studies. 2016. Vol. 6. № 3, pp. 7-11. DOI: 10.12731/2227-930X-2016-3-2.

9. Seliverstov N.D. Selection of asphalt-concrete mixed compositions in cold recycling of road surfaces // Polymer Science. Series D. 2016. v. 9. № 1, pp. 106-109.

\section{DATA ABOUT THE AUTHORS}

Izmaylova Dilyara Kyazymovna, Ph. D., Ass. Professor Department Economics of Road Transport

State Technical University - MADI

64, Leningradsky prospekt, Moscow, 125319, Russian Federation izmailovadk@list.ru

Seliverstov Nikolay Dmitrievich, Ph. D., Ass. Professor Department Road-building machinery State Technical University - MADI 64, Leningradsky prospekt, Moscow, 125319, Russian Federation seliverstov_nd@inbox.ru 